\title{
Application of Regional Security Complex Theory in Electoral Management, a View of East African Region
}

\author{
Thomas Otieno Juma* \\ Department of Humanities, School of Arts and Social Sciences, University of Kabianga, Kericho, Kenya
}

Submission: June 26, 2020; Published: September 14, 2020

*Corresponding author: Thomas Otieno Juma, Department of Humanities, School of Arts and Social Sciences, University of Kabianga, Kericho, Kenya

\begin{abstract}
The usage of Regional Security Theory is rampant in many areas of traditional security. It has not so much been applied to non-traditional security areas such as elections. The paper sought to find applicability of RSCT on the backdrop of the fact that many previous elections have been marred by intrastate violence, conflict laden electoral management dynamics (political architecture, systemic models, operational issues, and security strategies) which have unprecentedly caused threats to the East African regional security architecture in socio-eco-political perspectives. Despite inherent complexities that exist in Inter-State Security Arrangements (ISSA) due to functional-structural weakness of core state institutions, additionally, the researcher focused the study theoretically using Buzan and Waever's Regional Security Complex Theory (RSCT) in Regions and Power which address areas of internal "security interdependence" and securitization among states linked geographically to find its significance to non-traditional security context. The theory's multi-dimensional nature fits different settings as a way of theorizing securitization and was interesting within the neo-liberal regimes set by regionalization in the East African Region.
\end{abstract}

Keywords: Regional Security; Security Complex; Electoral Management; East Africa; Traditional Security; Non-Traditional Security

\section{Regional Security Complex}

Buzan and Wæver have defined regional security complexes as follows: The central idea in RSCT is that, since most threats travel more easily over short distances than long ones, security interdependence is normally defined into regionally based clusters: security complexes. Process of securitization and thus the degree of security interdependence are more intense between actors inside such complexes [1,2]. The regional security complexities arising out of electoral management seem to have been constantly building and increasing with the sunset of cold war into the period marked by calmness from the conflicts of coups and takeovers in Africa [3].

Regional Security Complex Theory (RSCT) has been used in different scenarios by scholars in attempts at arriving at regional security solutions. In these attempts, it is recognized that national militaries remain the principal actors in security among states. The issues though arising with effects of globalization, integrations, and governance lead to creation of porous borders and dilemmas which cooperate security can solve. The common lines of thought addressed many RSCTs surround; the role of insular/outlier states, the use of regional security community, and the role dominant powers in shaping local security concerns and imperative of security interdependence.
Maclean Wayne while studying Regional Security Complex Theory (RSCT) and Insular States - 'Turkey', Wayne [4] discusses RSCT in this discourse in light of a comparative study of Europe and Middle East and addresses the behavior of Turkey as a buffer/ proxy state in shaping power politics in this region focusing on military political view of international politics. Here, an insular state is defined as that state which cannot create links but joins the larger regional security complexes and cannot be neutral. AlKhalifa [5] a doctoral dissertation, is comparative in nature with focus on Gulf Cooperation Council (GCC) and Association of South East Asian Nations (ASEAN) defense and security circumstances. In this study, the emphasis highlights that regional security community is not an alternative to regional inter-state relations because the community is super structural. The study identifies a clash in approaches and state roles (sovereignty, non-interference, and conflict avoidance for regional development). This study contends that dilemma exist in practice of regional security community by underscoring limitations of Revolution in Military Affairs (RMA).

In Reynolds [6] empirical application of RSCT, the securitization discourse in China's relations with Central Asia and Russia, he raises issues including military concerns of great 
powers in shaping local security concerns by revealing limitations to securitization of threats by local state actors that is to say the role of Russia and China in generating security interdependence in this region. Finally, the main contention herein is that the nature of security is fundamentally non-military and trans-national thus need for interdependence.

\section{Regional Security: Transcendental in Nature}

Without a doubt, the whole area of non-traditional security whether it be threats, issues, or challenges...has come to occupy a prominent place on the regional security agenda in recent years [7]. Menon thinks that this is very much in keeping with the 'widening', or 'broadening', of the security agenda which has occurred internationally [8]. Threats and other relevant challenges as Rolls suggest being taking eminence in regional security are widespread. They range from human migrations (forceful and voluntary), cross border crimes, and electoral management effects in states with cultural disjoints making nations finding their bases in two states or more is worrisome. These kinds of challenges as seen in East Africa Region need to keep with the dynamics of contemporary security agenda. The possible architect may need to adopt non- traditional security which allows a zone of community securitization.

Peter Hough writing on security issues, threats, and challenges has argued, "whilst there is a case to be made that military threats in the twenty-first century are as apparent as ever and may be even greater than during the Cold War, the simple fact remains that they are not the only threats that face states, people and the world as a whole" [9]. The assertion by Hough is supported with a degree of reasonable solution similar to Rolls and Melon. "Threats can emanate from other sectors, and thus the security agenda should be widened accordingly, is something which has gained increasing recognition amongst political leaders and policymakers" [10]. As a recognized fact, the issue of security emanating from mega effects that are transcendental should attract serious inter- state response. The East Africa Region may want to take steps towards such security frameworks with Kenya's 2007 electoral management effects in mind. As a region that is already under a robust integration agenda, stability means much to it. Secondly, the East African Community integration process has enhanced institutional development processes meaning further breakages from traditional security methods can be options for serious integration.

As to whether electoral management across the borders can be securitized, Hough [9] contends that "there is an agreement that non-military issues can become 'securitized' and hence be privileged with 'national security' status. This kind of securitization can take two forms. First, the identification of selected nonmilitary areas such as drug trafficking and civil emergencies which the capabilities of armed forces can respond to. Secondly, in the securitizing of a range of non-military problems ... [which] have domestic military repercussions, issues such as AIDS or environmental degradation ... may destabilize regional balances of power and trigger military conflict that the on looking government may be drawn into or be affected by in some capacity". In Rolls [7] forms of the securitization of non-traditional issues have been observable in the Association of South East Asian Nations (ASEAN) region thus in securitizing a range of non-traditional issues, and thus attaching the label of 'national security' to them, has been rightly recognised by the ASEAN states. This comes from the fact that there are problems which are beyond the capacity of any individual state to respond to and thus they require collective action and co-operation with extra-regional dialogue partners. In other words, the notion national security may soon need to be applied within the security community spectrum involving states. Its possibility hinges on the premise that major milestones that defuse inter- state differences are shed off.

Regionalism has many benefits to date to states. The benefits range from economic, social, and political. To benefit from such, it is recognized that violence arising from elections management like other non-traditional security issues have effects on states and can have beyond state implications (extra-state impact) thus a potent to regional and international stability. Other insecurities in these categories include trafficking, piracy, terrorism, economic crimes, and arms smuggling among many. In the wake of such, should states wait to see workable models of security regional by nature before embarking on theirs? This is the dilemma that many regions such as East Africa Region (EAR) find itself in. Electoral management can be one of such threats to warrant need for a workable security architect beneficial to the EAR states. A number of causes were put forward for the increase in the prevalence of non-traditional threats by the Association of South East Asian Nations (ASEAN) Regional Forum Report 2005, being stressed that they were products of interwoven political, economic, ethnic, religious and other factors and have emerged against diverse historical and cultural backgrounds. As the forum noted, these threats tended to be more diversified and had both intra-state and inter-state implications and propagated more rapidly than traditional ones and their effects were increasingly complex. The pursuit of extra-regional cooperation for many states may mean dialoguing among partner states - Regional Network of States (RNS) and exchanging information.

\section{East African Regional (EAR) Security Complexities}

The security concerns in East Africa Region period since independence are a reality. Why? The attention that it draws from the continental body African Union (AU), East African Community (EAC), and Inter- Governmental Authority on Development (IGAD) portray a place that is insecure. Not only is the region insecure, it also experiences security complexities by the fact that within 
the states themselves, there are internal dynamics that portend security threats beyond the states. This divergent institutional membership is interesting because it illustrates the complexity of the environment in which these security institutions operate. The Countries have different past colonialism orientations (Anglophone and Francophone) and the way ideological war was played on this scene is all signs of the complexities.

The complexities as diverse as they are illustrate how states and institutions in the region differ considerably in their perception of security; including their understanding of what issues in the region represent the most pertinent threats and what their ideas about how best to overcome such threats are [11] . It is somehow true that the need for security and economic wellbeing pushes Countries in this region to cluster in a number of inter- state outfits in a bid to seek survival. In attestation to the existing security condition in the East Africa Region, the East African Community (EAC) in its Peace and Security Strategies points to peace and security as pre-requisites for the success of the EAC Region Integration process. It is against this background that the Council of Ministers, upon recommendation by the Sectoral Committee on Inter State Security established an experts' group to develop a Regional strategy supported by a practical implementation plan. The strategy was adopted by the $13^{\text {th }}$ Council of Ministers meeting, held in November 2006 to guide EAC level interventions in the Peace and Security Sector [12]. The Peace and Security Sector remains very committed and dynamic in order to respond to the nature and form of the ever evolving security threats.

Article 124 of The Treaty for the Establishment of the East African Community recognizes the need for peace and security within the East African States [12]. The question is whether the commitment has been backed with a real response. Another area to really think of is going beyond round-table/ paper-work agreements to facing security concerns of the region. Still, as much as such strategies may exist, the development of electoral management security and other intra-state conflicts which are likely to pillage may require effective Extra - State Security Arrangement (ESSA), or Intra- State Security Arrangement (ISSA) built around RNS. The current strategy seems to stop at 'this will provide a good and conducive environment for peace and security'.

Another dilemma that has faced the East African regional (EAR) security has had to do with inter-state sucpicions, historical coups, existence of rebels, tribal/ethnic animosities, failed states, and currently the terrorism issue and the manner of intervention in national security matters which have external effects. With this environment, is there likely to be a need for Revolution in Military Affairs (RMA) within the states or among states neatly linked or can it call for Inclusive Security Response (ISR)? This study tries to explore these lines of thought by using RSCT of Buzan and Waever in mind. As neo-liberalism spread through the forces of globalization, Aning [13] builds an argument that due to the interconnectedness among key actors and players in Africa's conflicts, one should begin to describe them as security complexes. They can be understood within a thematic context, namely in terms of the trans-nationality.

\section{Gap in Regional Security Complex Theory in East Af- rican Region}

From the sample discourses above and others relating to RSCT there is a gap in tackling the area of securitization from regional institutional perspective. There is indication that security interdependence is very necessary. The researcher will however work on a closer framework surrounding regional security community in discussing security interdependence to elections management.

According to Buzan and Waever [14], writings on "Regions and Powers: The Structure of International Security", the concept of regional security complexes covers how security is clustered in geographically shaped regions. Security concerns do not travel well over distances and threats are therefore most likely to occur in the region. The security of each actor in a region interacts with the security of the other actors. There is often intense security interdependence within a region which creates dilemmas between regions, which is what defines a region and what makes regional security an interesting area of study. By making a comparative reflection on Kenya's 2007 and 2013 elections, the researcher wants to find security concerns arising out of elections management especially in EAC region and the complexities therein inherent.

Regional Security Complex Theory should not be confused with regionalism, a subset of International Relations which is concerned mostly with regional integration. Regionalism is the expression of a common sense of identity and purpose combined with the creation and implementation of institutions that express a identity and shape collective action within a geographical region [3]. According to Kammerud, many transitional democracies have socio-economic, ethnic, political, or religious cleavages that may be aggravated by elections (e.g. Kenya, India, Guyana, and Kyrgyzstan). There may be insurgent groups that threaten the integrity of the electoral process ... that routinely harms [15]. What is clearly captured in Kammerud is that the internal dynamics of young democracies are full of insecurity complexes which become security issues.

Waiguchu [16] poses a key question in matters of election related conflict of which security ranks very high. She asks; Can violence like that of elections be localized or is it obvious that election violence of a national nature has a cross boundary effect thus international in nature? Waiguchu's question raises arguments, on one hand it is true electoral violence can be localized but on the other hand when the intensity escalates, possibilities of it transcending beyond borders is very high. These schools of 
thoughts (Localization vis- a- viz Globalization) will guide the theoretical basis for this study. In this regard, globalization school finds itself as an attribute of Regional Security Complex Theory. San Juan [17] too indicates that, the idea of violence in states as very much having the likelihood of exhibits beyond localization.

With an evidently changing pattern in the nature of conflicts, the possibility of elections management developing another ugly economic, social, and political history in the region need to be checked by the Regional Security Complex (RSC) arrangement for the thriving of East Africa Community (EAC). The changing nature of conflicts tend to show that many intra-state conflicts are becoming electoral related as opposed to the post- independent period characterized by numerous coups and takeovers. With a very strong assertion, Renner [18] mentions the changing interstate security dimensions in interconnected world as, security in a globalizing world cannot be provided on a purely national basis, or even on basis of limited alliances. A multilateral and even global approach is needed to deal effectively with a multitude of transboundary challenges. Regional Security Complex (RSC) involves security issues of states that transcend either one region or within states in one region as East African Region (EAC).

In application on the Central Asia security complexities, [6] observes a need of great powers in shaping regional security which is within their locality. And here China and Russia's role is in focus. The discourse suggests that existence of strong powers make security interdependency an option in a region like Asia. This limits securitization threats. In this kind of arrangement and application of Regional Security Complex Theory (RSCT), nontraditional security methods (non-military approach) becomes very appropriate. Al-Khalifa [5] in a look at Gulf Cooperation Council (GCC) and Association of South East Asian Nations (ASEAN) states comes up with a study which highlights another dimension to Regional Security Complex (RSCT), in terms of regional Security Community (SC), and it exposes a super structural approach. In this discourse however, both interdependence and institutionalism are being applied side by side.

One reason why state may use a dual security approach as postulated by Al-Khalifa may be due to considerations of realists understanding of state sovereignty a concept which seem to bind states despite thriving of neo-liberalism through globalization onslaught. Another issue of consideration for the Gulf Cooperation Council (GCC) and Association of South East Asian Nations (ASEAN) states is practice of non-interference policy of state relations which leads to an attempt to avoid conflict. This argument is anchored on a thought that for development to be harnessed there is need for relative stability. Election's management resulting conflict and violence cause threats that have wider geographic area that cannot be a Country's affair because of its likely effects. This poses a challenge to regional security/insecurity among neighbouring states. As it occurs, in the context of Regional Security Complex
Theory (RSCT), questions arise whether continual use of long cherished traditional security measures and approaches 'military - led' can enhance functional- structural weaknesses.

Election's management dynamics for regionally connected states qualify the application of the regional security complex theory because of complex processes interwoven with threats which are likely to polarize countries within proximity. Asunka [19], "electoral process is constituted from a complex series of interdependent sub-processes, generically including: civic education, voter education, voter registration, party registration, candidate nomination, the campaign period, polling operations, tallying and counting, dispute resolution and the official announcement of results. Each of these sub-processes can be characterized by different types of threats, influenced by the particular approach adopted, cross-influence between subprocesses and the individual circumstances of the election." However, elections following best practices free themselves from threats which are synonymous with poorly conducted elections.

The failure of traditional security approach may lead to change of approach. Regional Security Complex Theory (RSCT) as stipulated by Buzan and Weaver may cater for ensuing security which brings cross border effects even in elections to the geographically adjacent states in an era where factors promoting interdependence in social and economic fronts are ever on the rise (trade/ movements/e.t.c.) then a consideration for non- traditional security approaches might well be embraced (security community). Knowing fundamentally that a Country's insecurity is not remote to its neighbours from whichever cause they are likely to antagonize the existing peace and security regionally. States with their internal dynamics as Al-Khalifa [5] points remain sovereign entities. In adopting the spirit of Regional Security Complex Theory (RSCT), how then should they carry out securitization without infringing this attribute of state yet still act towards its survival. State survival is an element that means that this entity is not likely to be extinct due to underlying threats. If states are faced with insurmountable threats, they can disappear (the world has seen states come and go due to their ephemeral nature). It is on this view that this study theorizes that weaknesses of states are constant factors. In overcoming them and enhancing survival, states need to build stronger national institutions to address threats facing them or cooperate security wise by developing such institutions at regional level.

Where national institutions do not seem to deal with its security concerns, a thought of Institutions' Perspective Theory (IPT) can be attempted. As in Buzan and Waever [14], security is indeed clustered in regionally networked states, threats have no boundaries and security interdependence is not just a need but intense interdependency. This research therefore wishes to explore whether IPT can enhance this dependency further. When applied at the regional level then it can be referred to as Regional 
Institutions' Perspective Theory (RIPT). Institution theorists may borrow this projection by Scott, institutional theory attends to the deeper and more resilient aspects of social structure. It considers the processes by which structures, including schemes, rules, norms, and routines, become established as authoritative guidelines for social behavior. It enquires into how these elements are created, diffused, adopted, and adapted over space and time; and how they fall into decline and disuse. Although the ostensible subject is stability and order in social life ...conformity but to conflict and change in social structures [20].

The major concerns of Regional Institutions' Perspective Theory (RIPT) surround structures, stability, order, and a reality of decline of institutions. It is thought herein that security complexities can often be evaluated against institutions from time to time. Institutional theory run richly through the formative years of the social sciences, enlisting, and incorporating the creative insights of scholars ranging from Marx and Weber, Cooley, and Mead, to Veblen and Commons. Much of this work, carried out at the end of the nineteenth and beginning of the twentieth centuries, was submerged under the onslaught of neoclassical theory in economics, behavioralism in political science, and positivism in sociology, but has experienced a remarkable renaissance in our own time [21-23].

Defense and security are generally prime concerns of states. The necessity of this concern does not only find eminence to states alone rather in this period of regionalization and integration, but it becomes more pronounced among inter-state cycles because of interdependency. The adjacency of states makes it a real issue in regional politics as far as security is concerned. Theoretical foundations of 'realpolitik' become weakened by the likely effects of electoral management to neighbouring states, which in a way calls for considerations of reliance on enhanced foundations of institutions under neo-liberalism. The visible election management structural- functional weaknesses need adequate responses from a community of states to curtail the security concerns arising from such a vital exercise to create socio-ecopolitical imbalances in international affairs. The Asian and Gulf regions security situations have been an aspect of study by many. Al- Khalifa in his [5] dissertation examines the defense and security circumstances of the two regions and the responses of the regions' by looking at governments severally and cooperatively. His study has had to take account of the geographic, historical, ethno-cultural differences between the two regions. These are shown to be influential in their respective security responses.

The guiding framework in the application of this theory of Regional Security Complex Theory (RSCT), developed by Buzan and Waever [14] in Regions and Power is that Regional security complexes portray areas of internal security interdependence and securitization thus interlinking state operations within a region (intra-security linkage) and still also creating inter-regional security links. Why security interdependence? Newman and Selm [24] postulate a new rigour in understanding security as human security. They say human security is concerned with the protection of people from critical and life- threatening dangers, regardless of whether the threats are anthropogenic activities or natural events, whether they lie within or outside states, and whether they are direct or structural. It is "human- centred" in that its principal focus is on people both as individuals and as communal groups.

The issues of security above by Newman and Selm can be evaluated thus, security whether in the realms of the state effects or across the border effects is centered on people and hence human security by nature. In the perspective of Kenya's 2007 electoral management and East African regional security, threats to security can emerge or may be rooted in the societies. In light of Kenya's 2007 election aftermath, what is considered emerging is basically triggered from natural events. A close relationship lies between anthropogenic activities and security as well as natural events and security. Security within and between states often involve the aspect of human security which encompasses people and their properties. According to realists, security should be carried by states, however, with inherent conditions due to accelerated inter- connections, states are weakened by many factors in neo-liberalism regime which calls for reconstruction through the same design. For proper security checks and balances, cooperation can suffice. This design provides institutional support system to back discrepancies arising from the states. However, the role of states as the effecting entities of interdependency decisions cannot be demeaned. Newman and Selm [24] aver that contemporary security, if it is to be relevant to changing conditions and needs, must focus on the individual or people collectively... traditional conceptions of state security based on military defense of territory are important but not a sufficient condition for human welfare. This portrays a connection with Buzan and Waever's thesis of intra security linkages among states.

For the region in study (the East African Community subregion), fundamental research findings that the researcher will endeavour to find is the possibility of regional security community in the East Africa Region in the wake of election insecurity. As states interrelate in such a security arrangement, what are the likely roles of other actors given the historical background of this part of Africa? The effects of regionalization and the traditional feeling of statists by some Countries and foreign policy pursuance at the same time will enrich this study. Traditionally, the statists in Regional Security Complex Theory (RSCT) always perceive national military as the prime actors in regional security within their borders. Whereas RSCT postulates an environment where jeopardized security may call for serious military relation, in this region, with peripheral states like (Democratic Republic of Congo, Somalia, and South Sudan) yet closely attached to the region and which region is in constant experience of internal instabilities, one can ask whether a supra security organization can do better. In this 
sense it calls for evaluating possibilities of cooperating strategies to single- entity strategies.

Buzan and Weaver put it thus cooperation among states in security matters is not an option by the fact of being set of units whose major processes of securitization, desecuritisation, or both are so interlinked that their security problems cannot reasonably be analyzed or resolved apart from one another.... Processes of securitization and thus the degree of security interdependence are more intense between the actors inside such complexes than they are between actors inside the complex and those outside it. Al- Khalifa [5] defines this complex as RSCs are defined by durable patterns of amity and enmity.... Historical hatreds and friendships, as well as specific issues that trigger conflict or cooperation, take part in the formation of an overall constellation of fears, threats, and friendships [1]. It is agreeable to note the kinds of patterns that emerge among neighbouring states. Points of differences arise where classical realism is exercised whereas interdependency develops where a single state as an entity cannot tackle its issues and where also the spread is likely to be detrimental to international peace. Still in Regional Security Complex, Wayne [4] observes that, States that exist on the periphery of regions have a conspicuous role in the international system that has consistently challenged scholars. Here, minor states such as Afghanistan and Vietnam have shaped great power politics despite their relatively weak strength and positions in international affairs. Realist approaches have sidestepped these outlier states by calling them buffers or proxies.

Neo-liberalist perspectives have generally ignored states that paradoxically have had an impact on international relations that is disproportionate to their economic wealth and institutional engagement. Turkey represents an excellent case through which to examine these so-called 'outlier' states as in Wayne. Turkey has traditionally occupied a position at the periphery of both Europe and the Middle East, and until recently has shared the traits of many other outlier states by articulating a neutralist foreign policy. The position of outlier/peripherial states even though very confusing where they belong in a region have had some impact to the region's security. Turkey therefore fits into a hybrid web of constructivist-structuralist Regional Security Complex Theory (RSCT) here. Waiguchu [16] contends with the subject of elections having extra territoriality effects which in themselves are security concerns. It is in a way confirming that localization of security concerns emanating from election management is not a possibility for regionally adjacent states.

\section{Conclusion}

\section{Parallels and Paradoxes in Security Theory}

The critical application of Security Theory (ST) consists of two parallel arguments. Firstly, it calls for the critical evaluation of the structural power inherent within the securitizing process and demands that the security analyst deconstruct the institutional power of the securitizing actor and seek out alternative 'utterances' of security. Secondly, it requires that the security analyst critically engage with the symbolic power of security by critiquing dominant security subjectivities and necessitates the incorporation of alternative approaches to securitization [25].

Securitization is the intersubjective establishment of an existential threat, which demands urgent and immediate attention, as well as the use of extraordinary measures to counter this threat [26,27]. "Based on a clear idea of the nature of security, securitization studies aims to gain an increasingly precise understanding of who securitizes, on what issues (threats), for whom (referent objects), why, with what results and, not least, under what conditions (what explains when securitization is successful)" [26]. On this premise RSCT takes the objective of the Copenhagen School.

In electoral context, this study points that existing scholarly work evaluate state or international elite's utilization of security policy as an instrument to maintain order, preserve their power structures, or to pursue political interests. The state is able to play off the symbolism of its own authority, as the protector of the polity and provider of security, and use its institutional position in order to advance policies that regenerate and secure this imagery $[28,29]$. The last phase of the bipolar era unveiled the importance of other than military sources of threats, while concepts such as comprehensive and cooperative security were advanced in intergovernmental fora [30]. Waltz posits, despite the criticism of Strategic Studies advocates there is a widening move developed in the literature [31], this reflects the progressive loss of pre-eminence of the military dimension and of the State in security affairs [32]. This according to Davi [33] confirms why the question of different non-military threats has led to the analysis of the related targets across different sectors, ranging from the environmental to the economic from the political to the societal [34-38].

\section{References}

1. Pratama CP (2013) Central Asia as a Regional Security Complex from the Perspectives of Realism, Liberalism and Constructivism.

2. Baylis J, Smith S (2013) The Globalization of World Politics: An Introduction to International Relations. $2^{\text {nd }}$ ed. New York, NY: Oxford University Press. (2) (PDF) State Security, Societal Security, and Human Security.

3. Juma TO, Ken 0 (2012) Political Insights into African Democracy and Elections. Lamber Academic Publishing, Germany.

4. Wayne M (2014) Regional Security Complex Theory and Insulator States: The Case of Turkey. University of Tasmania.

5. Mohammed AKT (2012) The Gulf and Southeast Asia: Regional Security Complex and Regional Security Community, A comparative study. A dissertation for the Degree of Doctor of Philosophy in the Institute of Arab and Islamic Studies, University of Exeter. 
6. Reynolds JDA (2009) An Empirical Application of Regional Security Complex Theory: The Securitization Discourse in China's Relations with Central Asia and Russia. A Master of Arts in International Relations and security Studies Dissertation, Budapest: Hungary.

7. Rolls MG (2010) ASEAN and the Non-Traditional Regional Security Agenda. University of Waikato, Wellington, New Zealand. p. 1-8.

8. Menon S (2010) New Dimensions of Security. the Shangri-La Dialogue Summit, Second Plenary Session. Saturday 05 June the $9^{\text {th }}$ IISS Asia Security, India.

9. Hough P (2004) Understanding Global Security. London Abingdon: Routledge, p. 7.

10. Washington DC (1994) Government Printing Office. The White House, National Security Strategy of Engagement and Enlargement. Peter Hough, p. 1.

11. Jacobsen KL, Johannes RN (2013) Danish Interests in Regional Security Institutions in East Africa. DIIS REPORT Copenhagen, Denmark.

12. EAC (2015) Cooperation in Police Matters, EAC Police Security.

13. Aning K (2007) Africa: Confronting Complex Threats; Coping with Crisis. Working Paper Series, International Peace Academy.

14. Buzan B, Ole W (2003) Regions and Powers: The Structure of International Security. Cambridge, Cambridge University Press.

15. Kammerud L (2012) An Integrated Approach to Elections and Conflict. IFES White Paper.

16. Waiguchu JW (2012) Electoral Violence and Its Impact on The EAC Regional Economy: A Case Study of Kenya 2007- 2008 Violence. A Dissertation for The Award of a master's degree in International Relations and Diplomacy of Nkumba University.

17. San JE (2000a) After Postcolonialism. Lanham, MD: Rowman and Littlefield.

18. Renner M (2005) Introduction to the Concepts of Environmental Security and Environmental Conflict. Inventory of Environment and Security Policies and Practices. Global Security Project at the World watch Institute in Washington, DC.

19. Asunka J, Brierley S, Golden M, Kramon E, Ofosu G (2013) Protecting the Polls: The Effect of Observers on Election Fraud. University of California.

20. Scott WR (2004b) Institutional theory. In: George R, (ed.) Encyclopedia of Social Theory. Thousand Oaks, CA: Sage pp. 408-414.

21. Bill JA, Robert LH (1981) Comparative Politics: The Quest for Theory. Washington DC: Bell \& Howell, University Press of America.

22. Hodgson GM (1994) The return of institutional economics. In: The Handbook of Economic Sociology 58-76, Neil JS, Richard S, ed Princeton and New York: Princeton University Press and Russell Sage Foundation.
23. Scott WR (2001) Institutions and Organizations. Thousand Oaks, $2^{\text {nd }}$ (ed.). CA: Sage.

24. Newman E, Selm JV (2001) Refugees and Forced Displacement: International Security, Human Vulnerability, and the State. Un i te dNations University Press, Paris.

25. Charrett C (2009) A Critical Application of Securitization Theory: Overcoming the Normative Dilemma of Writing Security. International Catalan Institute for Peace, Barcelona (Spain).

26. Buzan B, Ole W, De Wilde J (1998) A New Framework for Analysis. Boulder: Lynne Rienner Publishers Inc.

27. Wæver Ole (1995) Securitization and Desecuritization. In: Ronnie L, On Security (ed.). NY: Columbia University Press.

28. Neocleous M (2008) Critique of Security. Edinburgh: Edinburgh University Press.

29. Risley S (2006) The Sociology of Security: Sociological Approaches to Contemporary and Historical Securitization. Working Paper presented at the American Sociological Association, Montreal.

30. Keohane RO, Wallander CA (1999) Risk, threat and security institutions In: Haftendorn H, Keohane RO, Wallander CA (eds) Imperfect Unions: Security Institutions over Time and Space, Oxford, Oxford University Press p. 21-47.

31. Walt SM (1991) The Renaissance of Security Studies. International Studies Quarterly 35(2): 211-239.

32. Sheehan M (2005) International Security: An Analytical Survey. Boulder, Lynne R.

33. Davì Marco (2009) Human Security as the One Size Fits All Policy Approach? European Security and Defence Forum Workshop 2: New Transnational Security Challenges and Responses. 11 November.

34. Höglund K, Anna KJ, Mimmi SK (2009) The Predicament of Elections in War-torn Societies. Democratization. 16(3): 530-557.

35. Sandbrook R (1975) Proletarians and African Capitalism: The Kenya Case, 1960-1972. New York: Cambridge University Press.

36. Sarantakos S (2005) Social Research. $2^{\text {nd }}$ edition, Palgrave Macmillan Hampshire.

37. Walzer M (1992) Just and Unjust Wars: A Moral Argument with Historical Illustrations. Second Edition. New York: Basic Books.

38. Global R, Michael (2005) Inventory of Environment and Security Policies and Practices. I-C. Introduction to the Concepts of Environmental Security and Environmental Conflict. New York. 15(1). 
Your next submission with Juniper Publishers will reach you the below assets

- Quality Editorial service

- Swift Peer Review

- Reprints availability

- E-prints Service

- Manuscript Podcast for convenient understanding

- Global attainment for your research

- Manuscript accessibility in different formats

( Pdf, E-pub, Full Text, Audio)

- Unceasing customer service

Track the below URL for one-step submission https://juniperpublishers.com/online-submission.php 